\title{
CHARACTERIZATION OF MIXED CRYSTALS OF SODIUM CHLORATE AND SODIUM BROMATE AND THE DOPED NICKEL SULPHATE CRYSTALS
}

\author{
M. Ajitha Sweetly ${ }^{1}$, T.Chithambarathanu ${ }^{2}$ \\ ${ }^{1}$ Physics Research centre, S.T. Hindu College, Nagercoil, Kanya Kumari, Tamil Nadu, India \\ ${ }^{2}$ Physics Research centre, S.T. Hindu College, Nagercoil, Kanya Kumari, Tamil Nadu, India
}

\begin{abstract}
The nickel sulphate doped mixed sodium chlorate and sodium bromate mixed crystal is grown by slow evaporation solution growth technique at room temperature. The grown crystal was subjected to XRD, UV, FTIR, SEM, TG/DTA, Microhardness and SHG analysis. Characterization studies reveal that the grown crystal forms cubic system with space group $P 2_{1} 3$. The crystal possesses less absorption in the UV-Visible region. The presence of various functional groups has been identified from FTIR studies with their vibrating frequencies. The second harmonic generation efficiency was also determined. The mechanical property was studied by microhardness.
\end{abstract}

Keywords: XRD, UV, FTIR, SEM, TG/DTA, Microhardness and SHG. $* * *$

\section{INTRODUCTION}

When two substances A and B have closely similar crystal structures, with not very different cell dimensions it is found that the atoms of one can replace those of the other indiscriminately in the lattice, resulting in a mixed crystal say $\mathrm{AB}$. In the present investigation, the mixed crystals of sodium chlorate and sodium bromate and nickel sulphate doped mixed crystals were grown and the harvested crystals were characterized by EDAX analysis, X-ray diffraction studies, microhardness measurement, SEM, TG/DTA analysis, SHG measurement, FTIR analysis, UV-Vis-NIR studies.

\section{SYNTHESIS, SOLUBILITY AND GROWTH}

All starting chemicals were of analytical reagent grade. The chemicals used were sodium chlorate, sodium bromate, nickel sulphate. Double distilled water was used as the solvent. The re-crystallized salts of sodium chlorate and sodium bromate were mixed in 1:1 molar ratio and dissolved in water to prepare saturated solution. This solution was stirred well using a hot plate magnetic stirrer and heated at $30{ }^{\circ} \mathrm{C}$ to obtain the synthesized mixed salt of sodium chlorate and sodium bromate. $0.5 \mathrm{~mol} \%, 1 \mathrm{~mol} \%$ and nickel sulphate was 1.5 mol\% doped with mixed crystals and the crystals were grown. Solubility studies were carried out by gravimetrical method [1]. The mixed salt was dissolved in double distilled water in an air right container maintained at a constant temperature using a hot-plate magnetic stirrer and a digital thermometer. The solution was stirred continuously at $30^{\circ} \mathrm{C}$ and the mixed salt was added till a small precipitate was formed to confirm the supersaturation. Then $5 \mathrm{ml}$ of the solution was pipetted out and taken in a petri dish and solvent was evaporated. By measuring the amount of salt present in the petri dish, the solubility was determined. Similar procedure was followed for all the samples. The solubility curves are shown in figures. From the solubility curves it is inferred that the solubility increases with increase of temperature and as these samples have positive temperature coefficient of solubility, they could be grown by slow evaporation technique [2]. 

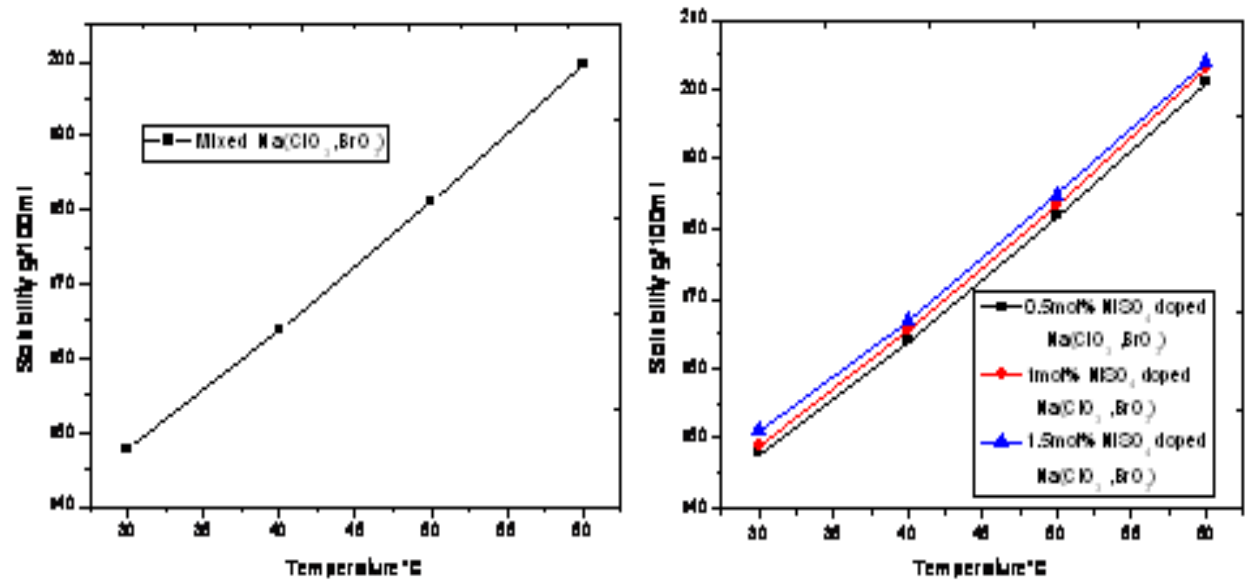

Fig: 1 Solubility curve for $\mathrm{Na}\left(\mathrm{ClO}_{3}, \mathrm{BrO}_{3}\right)$ mixed Fig: 2 Solubility curves for $\mathrm{NiSO}_{4}$ doped $\mathrm{Na}\left(\mathrm{ClO}_{3}, \mathrm{BrO}_{3}\right)$ mixed

Using the solubility data, the saturated solution of the mixed salt of sodium chlorate and sodium bromate was prepared at $30^{\circ} \mathrm{C}$ and stirred well for about 2 hours. Then the solution was filtered and it was taken in a petri dish for crystallization. The solvent evaporates and when it attains supersaturation, nucleation starts and the crystal grows. Over a period of 1015 days, well faceted optically transparent seed crystals of various dimensions were collected and shown in the figure.

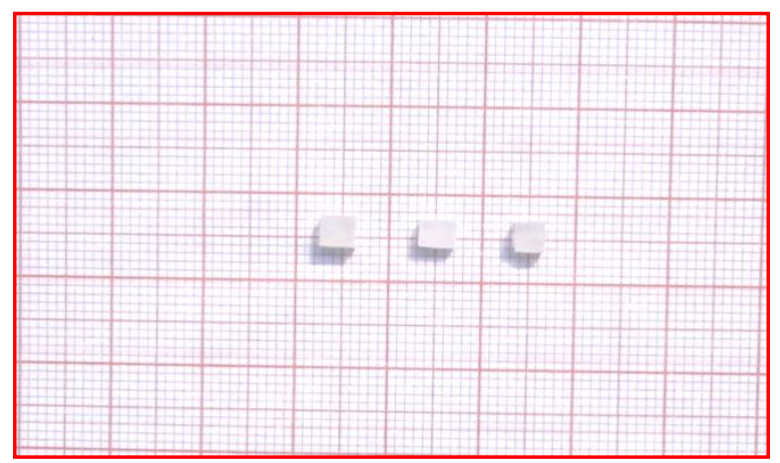

Fig: 3 Seed crystals of sodium chlorate and sodium bromate mixed single crystals

$0.5 \mathrm{~mol} \%, 1 \mathrm{~mol} \%$ and $1.5 \mathrm{~mol} \%$ of nickel sulphate was added as the dopant. Good quality seed crystals were selected and were placed at the bottom of the beakers containing the doped solutions. The beakers were covered with perforated polythene paper and they were kept in a vibration free platform at an average room temperature $29^{\circ} \mathrm{C}$. The excess of the solute was deposited on the seed crystals and the crystals grew into reasonable size crystals. Pure and doped crystals were grown in the period of 25 days. The grown crystals are shown in the figures. For the sodium bromate and sodium chlorate mixed crystal, the morphology is found to be cubic and well faceted [3-5]. The crystal was not found to be transparent. For the $\mathrm{NiSO}_{4}$ doped mixed crystals, the crystals posses the same cubical morphology and are transparent.

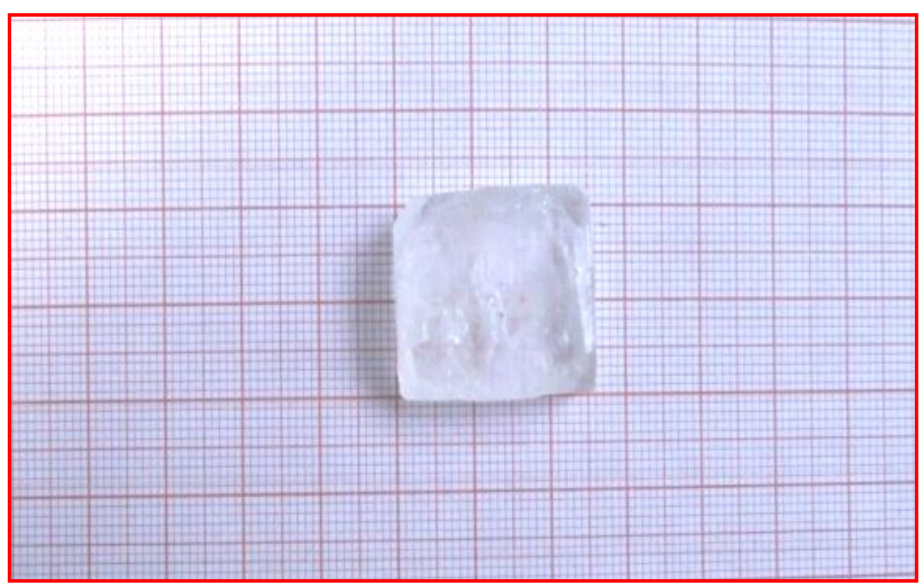

Fig: 4 Photograph of $\mathrm{Na}\left(\mathrm{ClO}_{3}, \mathrm{BrO}_{3}\right)$ mixed single crystal

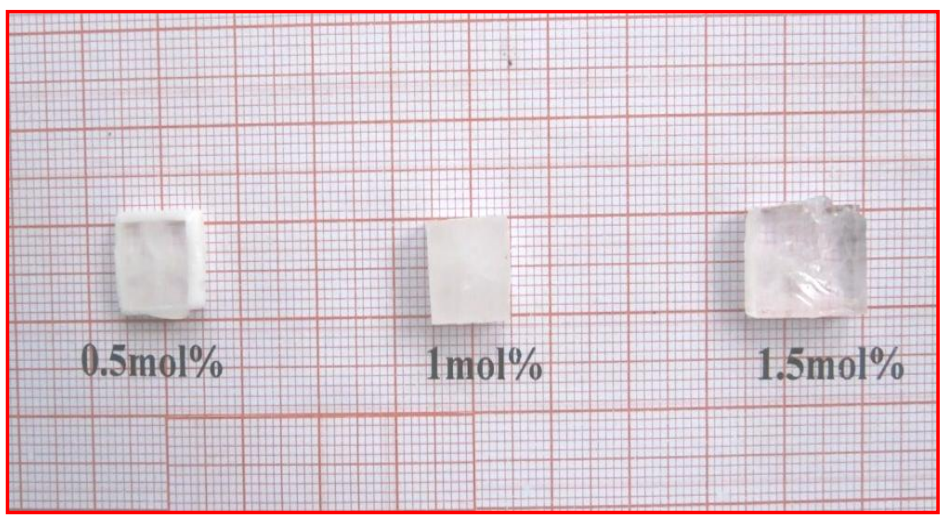

Fig: 5 Photograph of $0.5,1$ and $1.5 \mathrm{~mol} \%$ of nickel sulphate doped $\mathrm{Na}\left(\mathrm{ClO}_{3}, \mathrm{BrO}_{3}\right)$ mixed crystals 


\section{CHARACTERIZATION}

The FTIR spectra were recorded on PERKIN ELMER FTIR spectrometer in the range from $400-4000 \mathrm{~cm}^{-1}$. Powder XRD study was carried out on PHILIPS X'PERT MPD system using $\mathrm{Cu} \mathrm{K} \mathrm{K}_{\alpha}$ radiation. The TG/DTA was performed on NETZSCH Geratebau $\mathrm{GmbH}$ from room temperature to $900^{\circ} \mathrm{C}$ at a heating rate of $10^{\circ} \mathrm{C} / \mathrm{min}$ in nitrogen media. The UV-Vis spectra of pure and doped crystals were recorded using PERKIN ELMER LAMBDA-19 Spectrophotometer. For the measurement of SHG efficiency, the Kurtz Powder method was used by illuminating the powdered samples with fundamental (1064 nm) of a Q-Switched mode - locked Nd : YAG laser with input pulse of $2.7 \mathrm{~mJ}$.

\section{RESULTS AND DISCUSSION}

\subsection{EDAX Spectra}

Energy dispersive analysis by X-rays (EDAX) was used to verify the presence of different elements in the grown crystals. EDAX profiles have been recorded using a SEM and are shown in figures. The results confirm that the elements such as $\mathrm{Na}, \mathrm{Cl}, \mathrm{O}$ and $\mathrm{Br}$ are present in the mixed crystal of sodium chlorate and sodium bromate. The elements such as $\mathrm{Na}, \mathrm{Cl}$, $\mathrm{Br}, \mathrm{O}$ and $\mathrm{Ni}$ are identified in the sample of nickel sulphate added mixed crystal of sodium chlorate and sodium bromate.

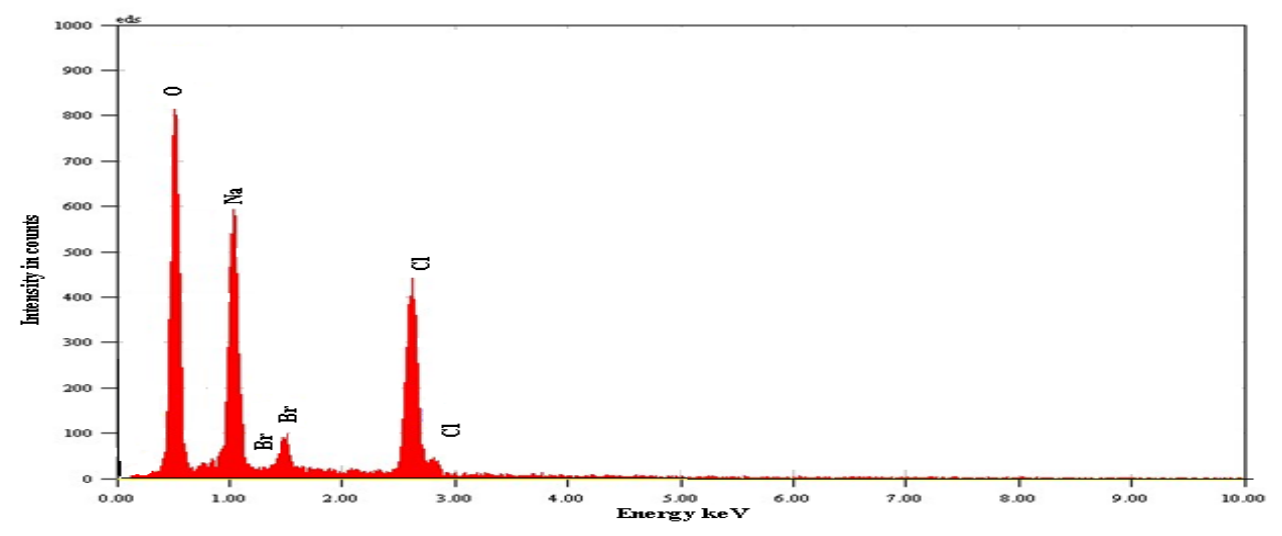

Fig: 6 EDAX spectrum of $\mathrm{Na}\left(\mathrm{ClO}_{3}, \mathrm{BrO}_{3}\right)$ mixed single crystal

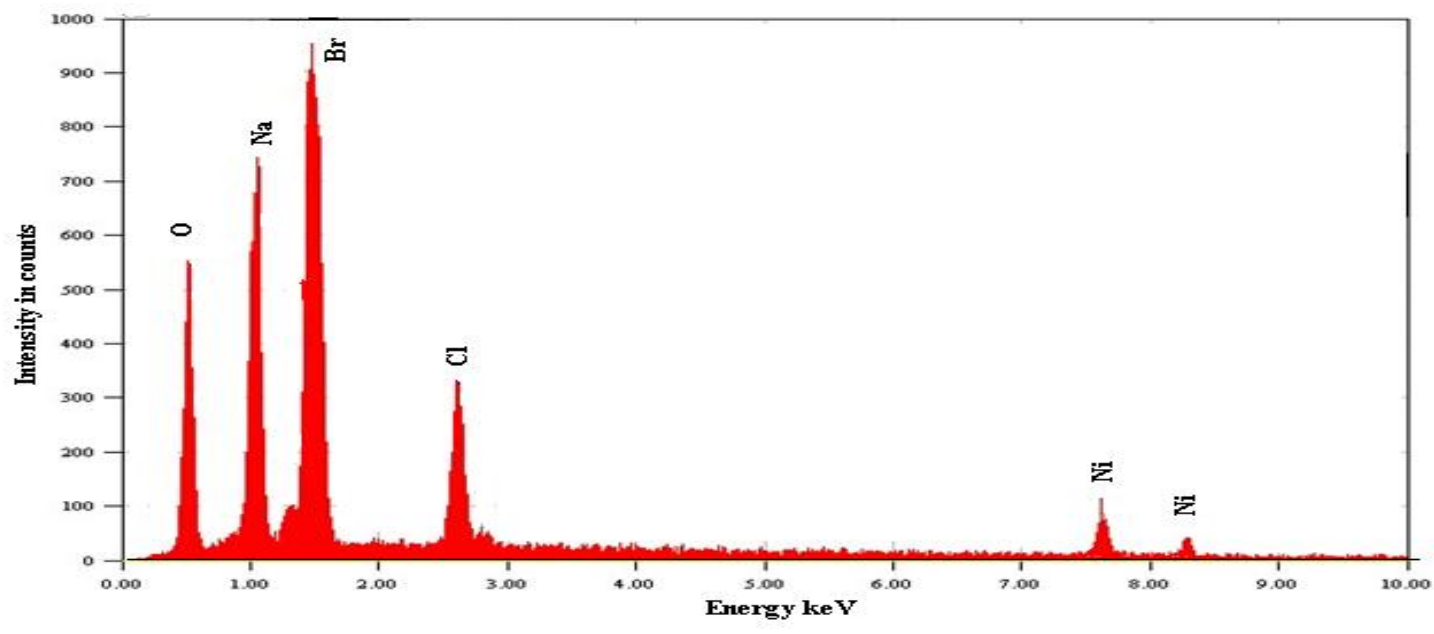

Fig: 7 EDAX spectrum of $\mathrm{NiSO}_{4}$ doped $\mathrm{Na}\left(\mathrm{ClO}_{3}, \mathrm{BrO}_{3}\right)$ mixed single crystal

\subsection{XRD Studies}

The powder XRD (PXRD) patterns of mixed sodium chlorate and sodium bromate, nickel sulphate doped mixed crystals are shown in figures. The powder XRD patterns give ideas about the crystallinity and phase purity. The reflections of the patterns were indexed following the procedures of Lipson and Steeple [6] using the TREOR and INDEXING software packages. Using the powder XRD data and the UNITCELL software package, the cell parameters have been found and the 
values are provided in the table. The powder XRD study was carried out for the confirmation of values and to identify the diffraction planes of the grown crystals. The powder XRD patterns obtained for the nickel sulphate doped mixed crystals are similar to that of the undoped mixed crystal with variations in the intensities of the diffracted peaks with slight shift in ' $2 \theta$ ' values. The sharp peaks indicate that the crystals have good crystallinity. The slight shift in $2 \theta$ values in the PXRD patterns of the doped mixed crystals values indicates that their lattice constants are slightly changed [7].

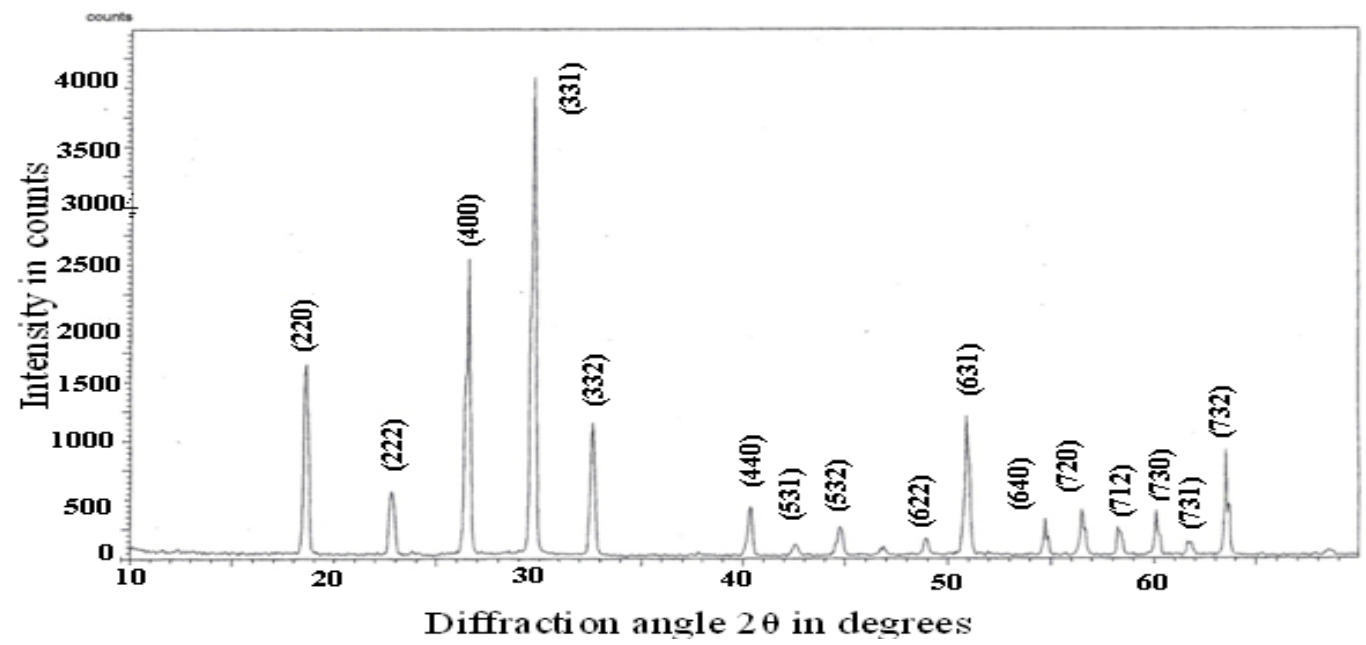

Fig: 8 Powder XRD pattern for $\mathrm{Na}\left(\mathrm{ClO}_{3}, \mathrm{BrO}_{3}\right)$ mixed crystal

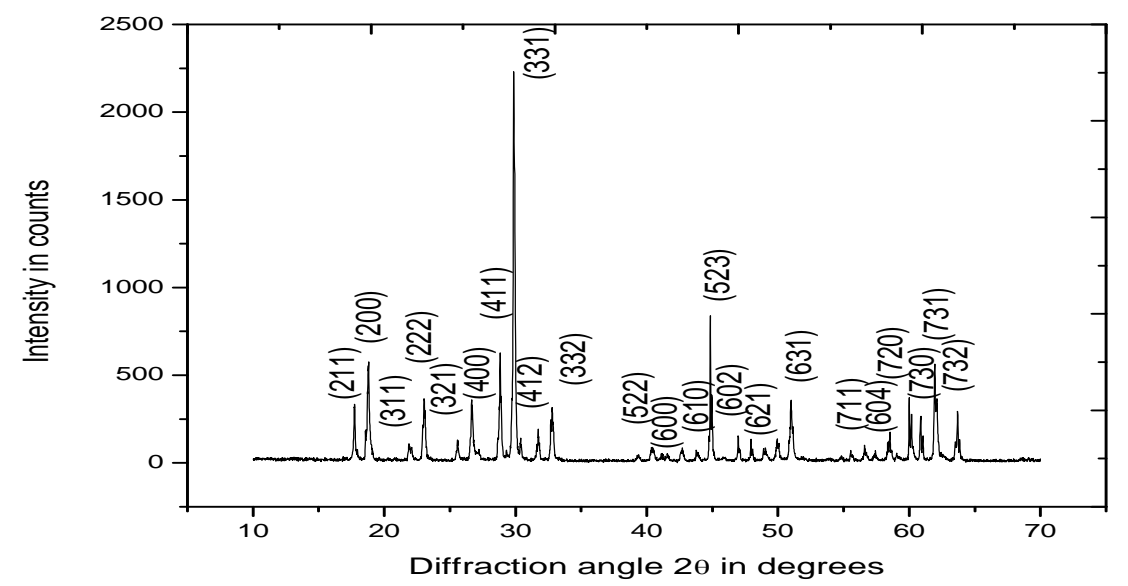

Fig: 9 Powder $\mathrm{XRD}$ spectrum of $\mathrm{NiSO}_{4}$ doped $\mathrm{Na}\left(\mathrm{ClO}_{3}, \mathrm{BrO}_{3}\right)$ mixed single crystal

Table: 1 Lattice parameters of pure and doped $\mathrm{Na}\left(\mathrm{ClO}_{3}, \mathrm{BrO}_{3}\right)$ mixed crystals

\begin{tabular}{|l|l|l|l|}
\hline Sample & $\begin{array}{l}\mathbf{a}=\mathbf{b}=\mathbf{c} \\
\mathbf{A}\end{array}$ & $\begin{array}{l}\text { Unit cell volume, } \\
\mathbf{V}(\AA)\end{array}$ & $\boldsymbol{\alpha}=\boldsymbol{\beta}=\boldsymbol{\gamma}$ (degrees) \\
\hline $\begin{array}{l}\mathrm{Na}\left(\mathrm{ClO}_{3} \mathrm{BrO}_{3}\right) \\
\text { crystal }\end{array}$ & 6.716 & 302.96 & 90 \\
\hline $\begin{array}{l}0.5 \mathrm{~mol}_{\mathrm{N}} \mathrm{NiSO}_{4} \text { doped } \\
\mathrm{Na}\left(\mathrm{ClO}_{3} \mathrm{BrO}_{3}\right) \\
\text { crystal mixed }\end{array}$ & 6.697 & 300.42 & 90 \\
\hline
\end{tabular}




\subsection{Hardness, Yield Stress and Stiffness Constant}

The microhardness measurement was carried out for pure and doped mixed crystals using a microhardness tester. This test was done at different applied loads varied rom 25, 50, 100 and $200 \mathrm{~g}$. The diagonal indentation length (d) was measured and the Vickers hardness number $\left(\mathrm{H}_{\mathrm{v}}\right)$ was calculated. The plots of Vickers hardness number versus load for the mixed and nickel sulphate doped crystals are shown in figures. The hardness number is increased for increase of load upto $100 \mathrm{~g}$ and after $100 \mathrm{~g}$ cracks started on the surface of the crystals. The increase in hardness with the load can be considered due to reverse indentation size effect [8] which involves a release of the indentation stress along away from the indentation site because of crack formation, dislocation activity or elastic deformation of tip of the indenter [9]. The work hardening coefficient ( $\mathrm{n}$ ) of the material is related to the load $\mathrm{P}$ by the relation $\mathrm{P}=\mathrm{ad}^{\mathrm{n}}$ where ' $\mathrm{a}$ ' is a constant called standard hardness.

The work hardening coefficient values for pure and doped mixed crystals are determined and are tabulated in the table. Here the hardness values are given in MPa and loads are given in newtons. In $0.5 \mathrm{~mol} \%$ of nickel sulphate doped mixed crystal the hardness number is found to be higher than the undoped mixed crystal. The work hardening coefficient is found to be $n>1.6$ and this shows that crystals belong to soft material category [10]. The plots of $\log \mathrm{P}$ versus $\log \mathrm{d}$ are shown in figures. Using the plots, the work hardening coefficient and the standard hardness were calculated.

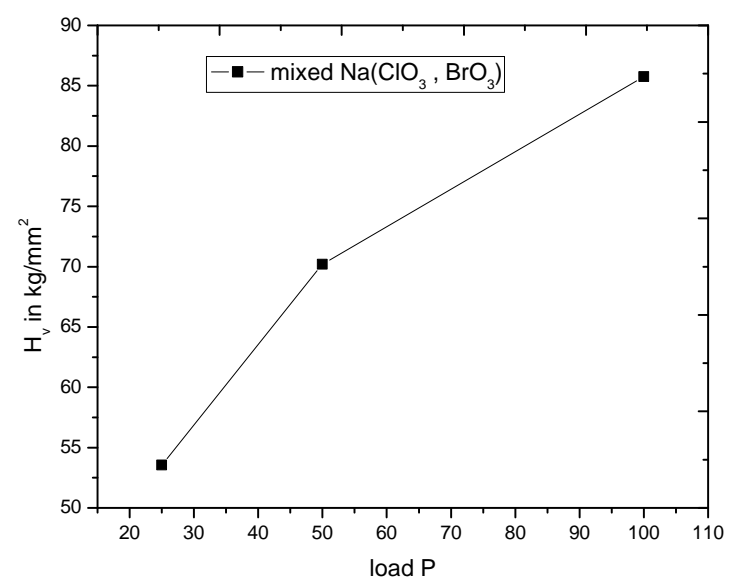

Fig: 10 Variation of Vickers microhardness number with the applied load for $\mathrm{Na}\left(\mathrm{ClO}_{3}, \mathrm{BrO}_{3}\right)$ single crystal

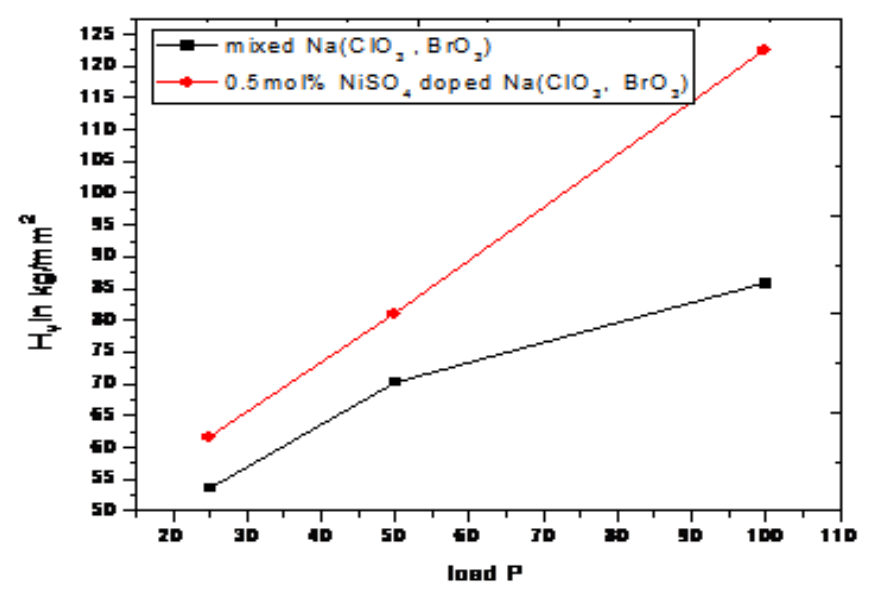

Fig: 11 Variation of Vickers microhardness number with the applied load for $\mathrm{NiSO}_{4}$ doped $\mathrm{Na}\left(\mathrm{ClO}_{3}, \mathrm{BrO}_{3}\right)$ single crystals

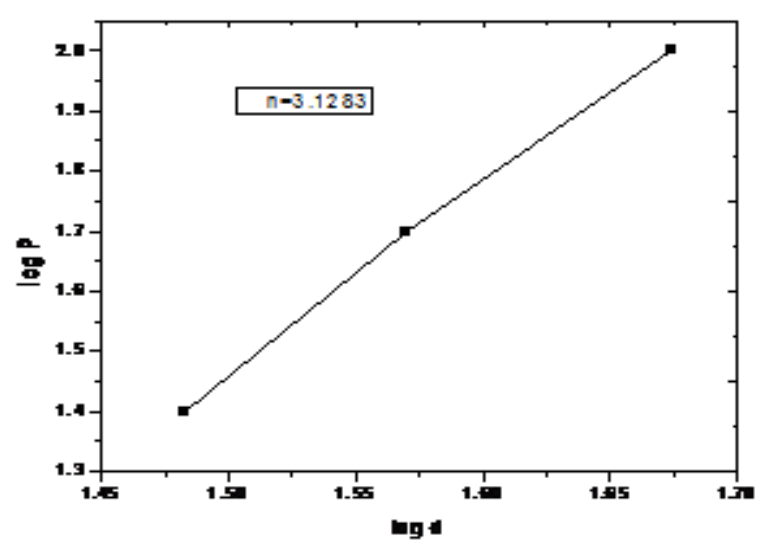

Fig: 12 Variation of $\log \mathrm{P}$ with $\log \mathrm{d}$ for $\mathrm{Na}\left(\mathrm{ClO}_{3}, \mathrm{BrO}_{3}\right)$ single crystal

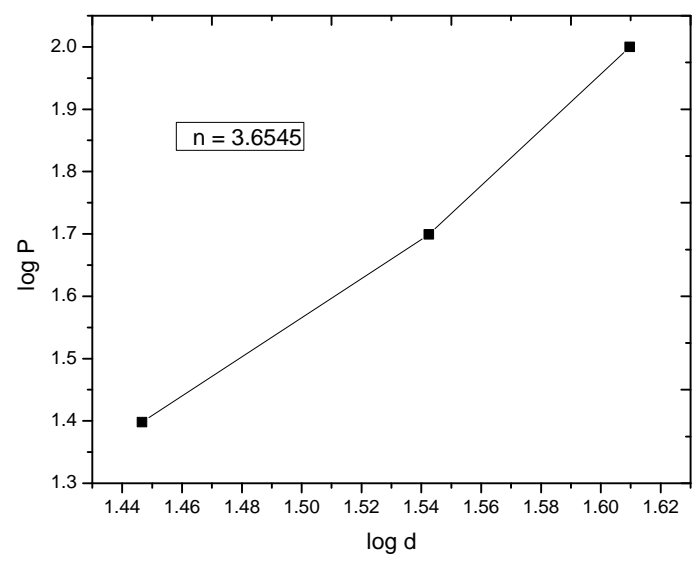

Fig: 13 A plot of $\log \mathrm{P}$ versus $\log \mathrm{d}$ of nickel sulphate doped $\mathrm{Na}\left(\mathrm{ClO}_{3}, \mathrm{BrO}_{3}\right)$ single crystals 
Table: 2 Hardness values of mixed and doped mixed crystal

\begin{tabular}{|l|l|l|}
\hline $\begin{array}{l}\text { Load } \\
(\mathrm{N})\end{array}$ & $\begin{array}{l}\text { Mixed crystal of } \mathrm{Na}\left(\mathrm{ClO}_{3},\right. \\
\left.\mathrm{BrO}_{3}\right)(\mathrm{MPa})\end{array}$ & $\begin{array}{l}0.5 \mathrm{~mol} \% \text { of nickel sulphate dopedmixed } \\
\text { crystal }(\mathrm{MPa})\end{array}$ \\
\hline 0.245 & 524.79 & 603.19 \\
\hline 0.490 & 687.97 & 793.31 \\
\hline 0.980 & 840.35 & 1200.5 \\
\hline
\end{tabular}

Table: 3 Values of Yield Stress, First order elastic stiffness constant and work hardening coefficient and standard hardness for $100 \mathrm{~g}$

\begin{tabular}{|l|l|l|l|l|}
\hline Samples & $\begin{array}{l}\text { Yield Stress, } \\
\sigma_{\mathrm{y}}(\mathrm{MPa})\end{array}$ & $\begin{array}{l}\text { First Order Elastic } \\
\text { Stiffness Constant, } \\
\mathrm{C}_{11}(\mathrm{MPa})\end{array}$ & $\begin{array}{l}\text { Work Hardening } \\
\text { Coefficient, } \mathrm{n}\end{array}$ & $\begin{array}{l}\text { Standard Hardness, } \\
\text { A (MPa) }\end{array}$ \\
\hline $\begin{array}{l}\mathrm{Na}\left(\mathrm{ClO}_{3}, \mathrm{BrO}_{3}\right) \\
\text { mixed crystal nickel }\end{array}$ & 280.117 & 131439.99 & 3.1302 & 188897.44 \\
\hline $\begin{array}{l}0.5 \text { mol\% of nit doped } \\
\text { sulphate } \\
\text { mixed crystal }\end{array}$ & 400.167 & 245388.85 & 3.6545 & 211946.42 \\
\hline
\end{tabular}

\subsection{FTIR analysis}

The FTIR spectrum of 0.5 mol\% of nickel sulphate doped mixed sodium chlorate and sodium bromate crystal is shown in figure. The band frequencies with assignments were summarized in table. The $\mathrm{OH}$ stretching vibration of water molecule is observed at $3409 \mathrm{~cm}^{-1}$ and $3113 \mathrm{~cm}^{-1}$. The absorption band at $2901 \mathrm{~cm}^{-1}$ is due to stretching of $\mathrm{Ni}^{2+}$ ions. The peaks at $2697 \mathrm{~cm}^{-1}$ and $2605 \mathrm{~cm}^{-1}$ corresponds to $\mathrm{Na}-\mathrm{O}$ stretching. The Br-O stretching is observed at $1906 \mathrm{~cm}^{-}$

${ }^{1}$. The absorption peak at $1720 \mathrm{~cm}^{-1}$ is due to $\mathrm{Cl}-\mathrm{O}$ stretching.
The peak at $1622 \mathrm{~cm}^{-1}$ is due to $\mathrm{O}-\mathrm{H}$ bending vibration of water molecule. The sharp band at $1497 \mathrm{~cm}^{-1}$ and $1408 \mathrm{~cm}^{-1}$ corresponds to $\mathrm{O}-\mathrm{Br}-\mathrm{O}$ stretching. The $\mathrm{O}-\mathrm{Cl}-\mathrm{O}$ stretching was observed at $1328 \mathrm{~cm}^{-1}$ and $1252 \mathrm{~cm}^{-1}$. The peaks at $1188 \mathrm{~cm}^{-1}$ and $1114 \mathrm{~cm}^{-1}$ indicates $=\mathrm{Br}-\mathrm{O}$ bending. The peak at $887 \mathrm{~cm}^{-1}$ corresponds to $\mathrm{BrO}_{3}$ rocking. The peaks at $670 \mathrm{~cm}^{-1}$ and 618 $\mathrm{cm}^{-1}$ is due to $\mathrm{ClO}_{3}$ bending. The peak at $505 \mathrm{~cm}^{-1}$ is due to torsional oscillation of $\mathrm{ClO}_{3}$.

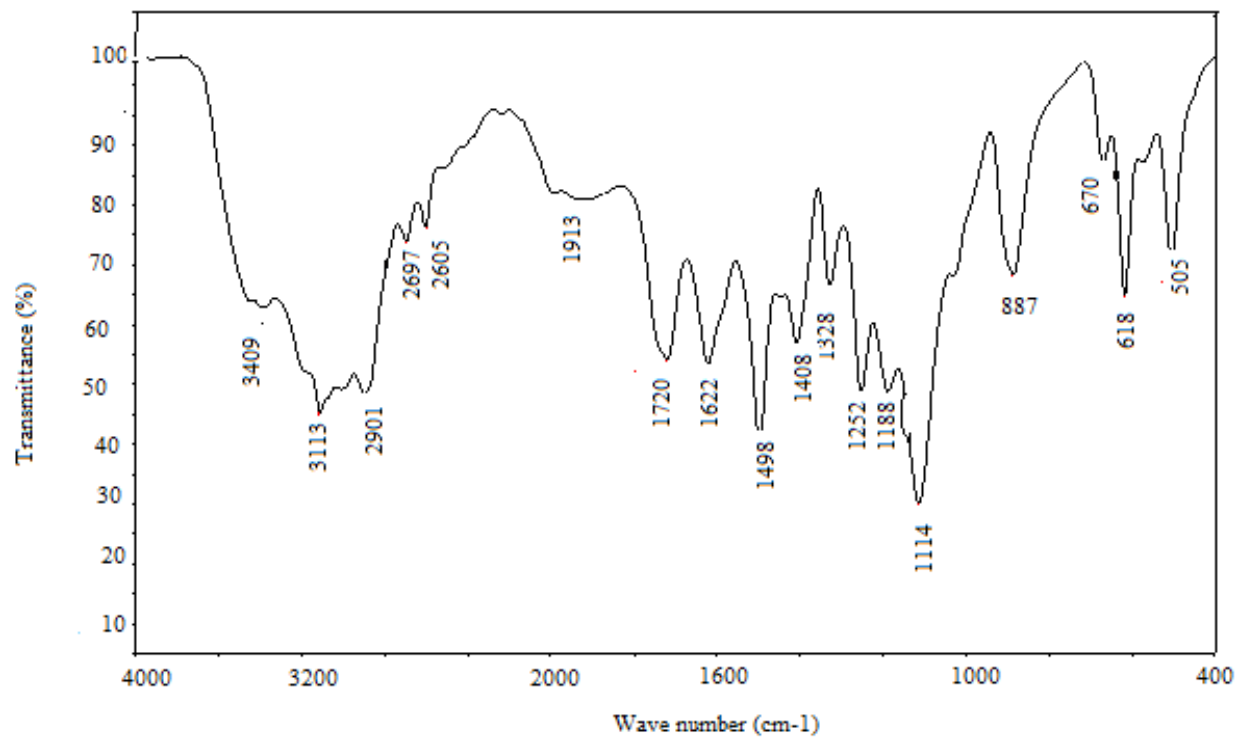

Fig: 14 The FTIR spectrum of $\mathrm{NiSO}_{4}$ doped $\mathrm{Na}\left(\mathrm{ClO}_{3}, \mathrm{BrO}_{3}\right)$ mixed crystal 
Table: 4 FTIR spectral assignments of $\mathrm{NiSO}_{4}$ doped $\mathrm{Na}\left(\mathrm{ClO}_{3} \mathrm{BrO}_{3}\right)$ mixed crystal

\begin{tabular}{|l|l|l|}
\hline Wave number $\left(\mathrm{cm}^{-1}\right)$ & Intensity & Assignments \\
\hline 3409,3113 & Strong & $\mathrm{O}-\mathrm{H}$ stretch \\
2901 & Medium & $\mathrm{Ni}^{2+}$ ion \\
2697,2605 & Sharp & $\mathrm{Na}-\mathrm{O}$ stretching \\
1913 & Sharp & Br-O stretch \\
1720 & Strong, sharp & Cl-O stretching \\
1622 & Strong, sharp & OH bending \\
1498,1408 & Strong, sharp & O-Cl-O stretching vibration \\
1328,1252 & Strong, sharp & O-Cl-O stretching \\
1188,1114 & Strong, sharp & =Br-O bending \\
887 & Strong, sharp & BrO rocking \\
670,618 & Strong, sharp & $\mathrm{ClO}_{3}$ bending \\
505 & Strong, sharp & torsional oscillation of $\mathrm{ClO}_{3}$ \\
\hline
\end{tabular}

\subsection{SEM Studies}

Scanning Electron Microscopic (SEM) studies were carried out for the grown crystals to analyse the surface features. The SEM image of the mixed crystal of sodium chlorate and sodium bromate is shown in figure. From figure it is confirmed that at $\times 2000$ and $\times 1000$ magnification, the surface is observed to be smooth and cloudy like features. Figure shows the SEM micrographs $0.5 \mathrm{~mol} \%$ of nickel sulphate doped $\mathrm{Na}\left(\mathrm{ClO}_{3}, \mathrm{BrO}_{3}\right)$ mixed crystal. At high magnification such as $\times 1000$ and $\times 2000$, the crystal surface was identified with clear plane.
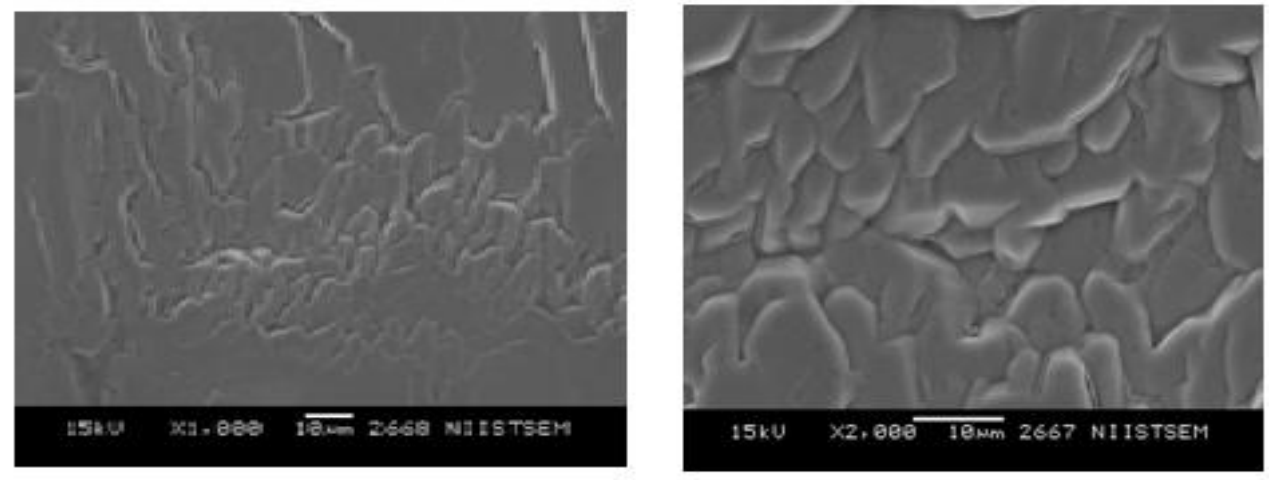

Fig: $15 \mathrm{SEM}$ images for $\mathrm{Na}\left(\mathrm{ClO}_{3}, \mathrm{BrO}_{3}\right)$ mixed single cryst
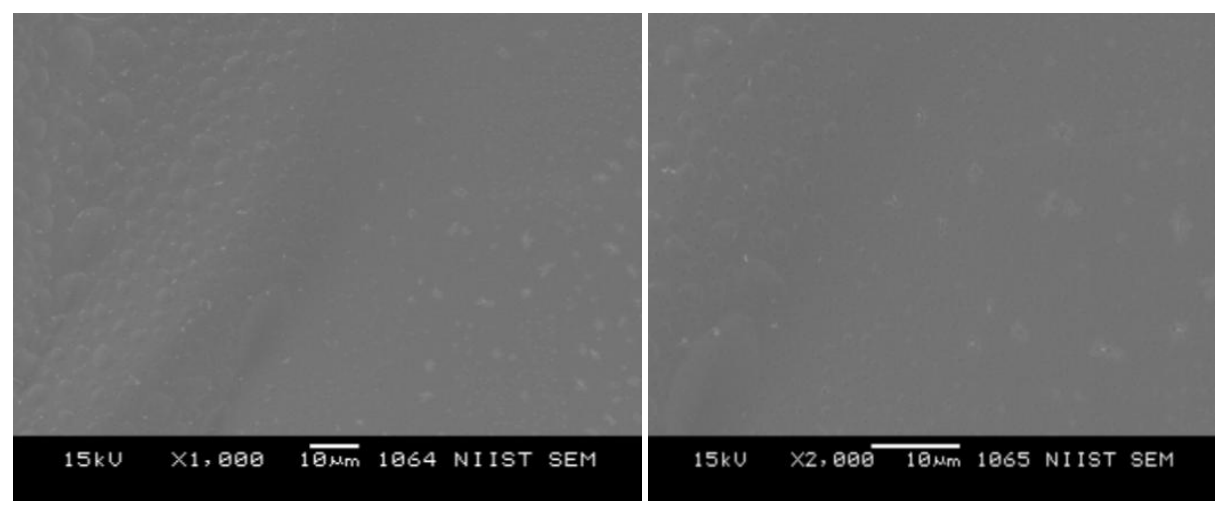

Fig: $16 \mathrm{SEM}$ images for $\mathrm{NiSO}_{4}$ doped $\mathrm{Na}\left(\mathrm{ClO}_{3}, \mathrm{BrO}_{3}\right)$ mixed single crystal 


\subsection{Thermal Analysis}

The TG/DTA curves for the mixed crystal of $\mathrm{Na}\left(\mathrm{ClO}_{3}, \mathrm{BrO}_{3}\right)$ are presented in figure. The initial mass of the material was taken to be $8.936 \mathrm{mg}$ and final mass left out after the experiment was about $2 \%$ of initial mass. The TG curve shows no weight loss upto $200{ }^{\circ} \mathrm{C}$. There was a major weight loss of $35 \%$ between $200{ }^{\circ} \mathrm{C}$ and $400{ }^{\circ} \mathrm{C}$. The decomposition point of mixed crystal is assigned as $200{ }^{\circ} \mathrm{C}$. The DTA curve shows two endothermic peaks at $360{ }^{\circ} \mathrm{C}$ and $740{ }^{\circ} \mathrm{C}$ and two exothermic peaks at $440^{\circ} \mathrm{C}$ and $525^{\circ} \mathrm{C}$. The sharp endothermic peaks reveal that the crystal has good degree of crystallinity [11].

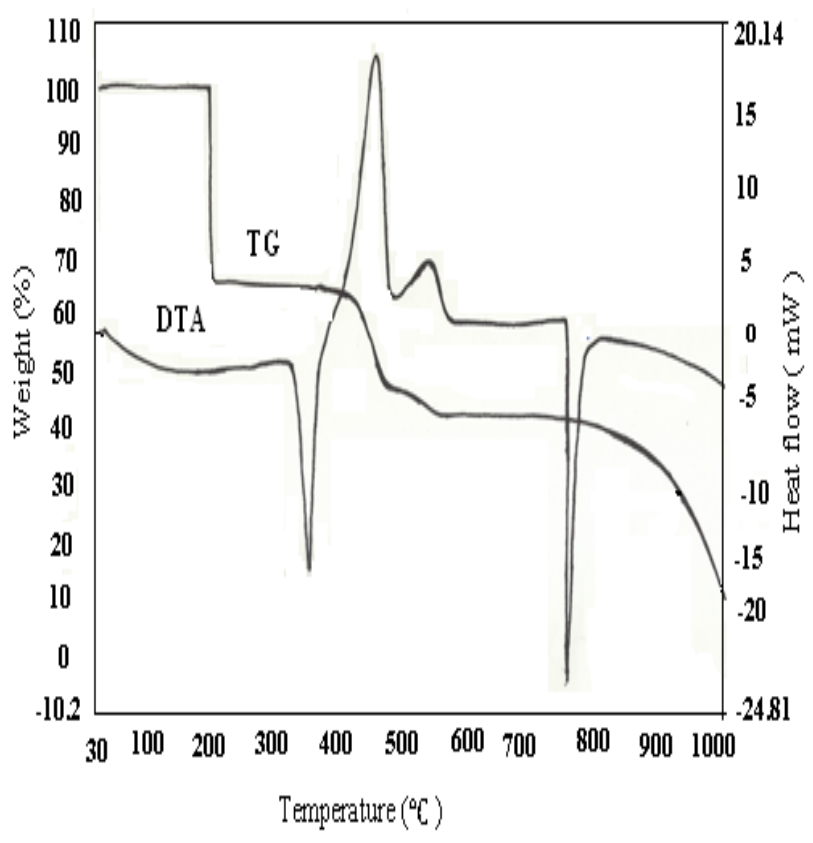

Fig: 17 TG/DTA thermal curves for $\mathrm{Na}\left(\mathrm{ClO}_{3}, \mathrm{BrO}_{3}\right)$ mixed crystal

The TG/DTA thermal curves for $0.5 \mathrm{~mol} \%$ of nickel sulphate doped mixed crystal is displayed in figure. The initial mass was $6.784 \mathrm{mg}$. From the TG curve it is observed that the crystal is stable upto $360{ }^{\circ} \mathrm{C}$ with $2 \%$ loss of mass. The residue left behind is found to be about $52 \%$ of the initial mass. The DTA curve shows two endothermic and one exothermic peaks. The first endothermic peak at $360.8{ }^{\circ} \mathrm{C}$ is due to the melting point of the crystal and second endothermic peak at $746.1{ }^{\circ} \mathrm{C}$ corresponds to the melting point of the residue. The exothermic peak at $388.8{ }^{\circ} \mathrm{C}$ gives the liberation of volatile substances.

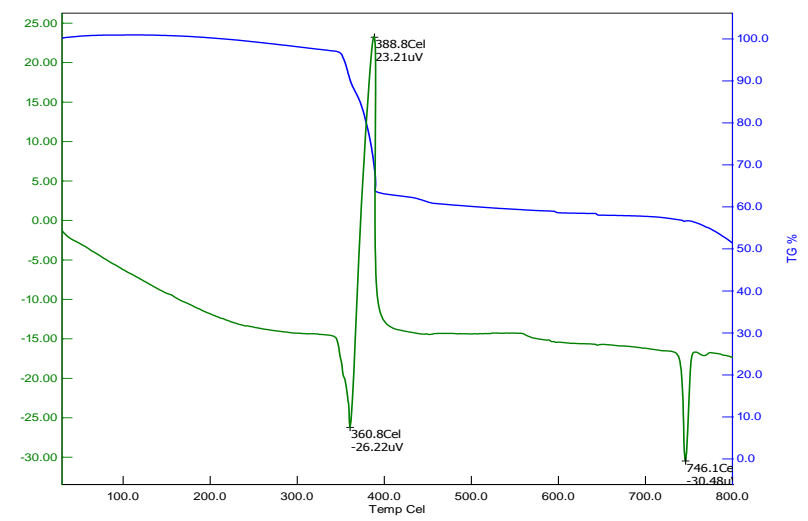

Fig: 18 TG/DTA spectra for nickel sulphate doped mixed single crystal

\subsection{UV-Vis Spectral Studies}

Good optical transmittance is important for the nonlinear optical crystals. The crystals can have practical use only if it posses transparency in the ultra violet, visible and near infrared regions (UV region 200-400 $\mathrm{nm}$, visible region 400$800 \mathrm{~nm}$ and near IR region 800-1100 nm). The thickness of the sample used was about $1 \mathrm{~mm}$. The UV-Vis-NIR transmission spectra of the samples are recorded in the range $190 \mathrm{~nm}$ to $1100 \mathrm{~nm}$. The UV-Vis-NIR transmission spectra of pure and nickel sulphate doped $\mathrm{Na}\left(\mathrm{ClO}_{3}, \mathrm{BrO}_{3}\right)$ mixed crystals are shown in figure and the figure represents that the transmission is good in visible and near infrared regions. The transmittance for nickel sulphate doped crystal was improved slightly. Tauc's plots for the samples were plotted for the samples and they are given in the figures. The optical absorption coefficient $(\alpha)$ and optical band gap for the undoped and doped mixed crystals of sodium chlorate and sodium bromate were determined. The samples have wide transparency and can be used in opto-electronic applications $[12,13]$.

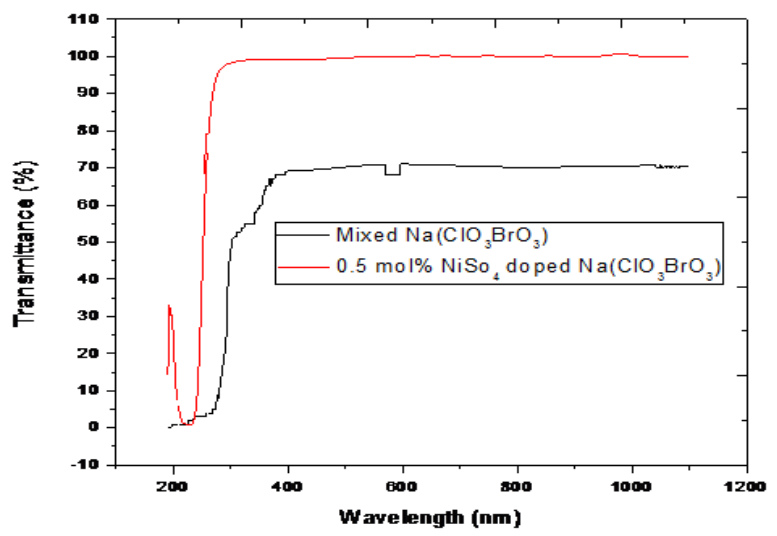

Fig: 19 UV-vis-NIR transmission spectra of pure and nickel sulphate doped $\mathrm{Na}\left(\mathrm{ClO}_{3}, \mathrm{BrO}_{3}\right)$ mixed single crystals 


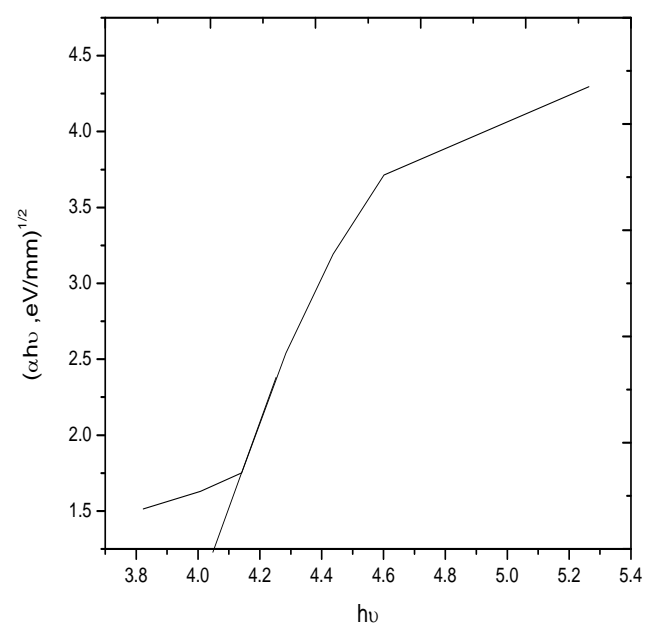

Fig: 20 Plot of hv versus $(\alpha h v)^{1 / 2}$ of $\mathrm{Na}\left(\mathrm{ClO}_{3}, \mathrm{BrO}_{3}\right)$ mixed single crystal

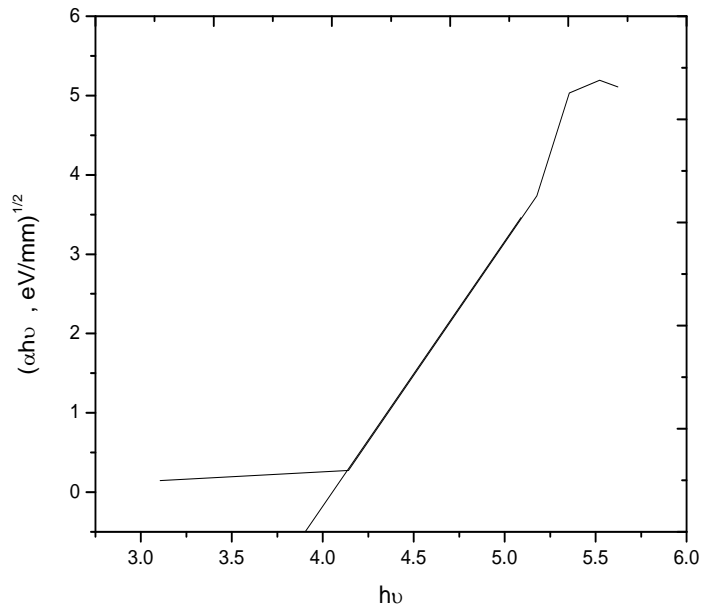

Fig: 21 Plot of hv versus $(\alpha h v)^{1 / 2}$ for nickel sulphate doped $\mathrm{Na}\left(\mathrm{ClO}_{3}, \mathrm{BrO}_{3}\right)$ mixed single crystal

Table: 5 Optical transmission data for pure and doped $\mathrm{Na}\left(\mathrm{ClO}_{3}, \mathrm{BrO}_{3}\right)$ mixed single crystals

\begin{tabular}{|l|l|ll|l|l|}
\hline Samples & $\begin{array}{l}\text { Optical transmission } \\
(\%)\end{array}$ & $\begin{array}{l}\text { Transparency } \\
\text { off }(\mathrm{nm})\end{array}$ & Cut- & \multicolumn{2}{|l|}{ Optical band gap $\left(\mathrm{E}_{\mathrm{g}}\right) \mathrm{eV}$} \\
\cline { 5 - 5 } & & Calculated values & From graph \\
\hline $\begin{array}{l}\text { mixed } \mathrm{Na}\left(\mathrm{ClO}_{3}, \mathrm{BrO}_{3}\right) \\
\text { crystal }\end{array}$ & $\begin{array}{l}70 \\
(350-1100 \mathrm{~nm})\end{array}$ & $\approx 305$ & 4.073 & 4.073 \\
\hline $\begin{array}{l}0.5 \text { mol\% of nickel } \\
\text { sulphate doped } \mathrm{Na}\left(\mathrm{ClO}_{3},\right.\end{array}$ & $\begin{array}{l}99.8 \\
\left.\mathrm{BrO}_{3}\right) \text { crystal }\end{array}$ & $\approx 320$ & 3.882 & 3.88 \\
\hline
\end{tabular}

\subsection{NLO Characterization}

The most widely used technique for confirming the SHG property is Kurtz and Perry power technique. The origin of nonlinearity in the NLO materials is due to the presence of $\pi$ electron systems, connecting donor and acceptor groups having asymmetric polarizability. The distribution of valence electrons of the metallic elements strongly affects the linear and nonlinear properties of each type of constituent chemical bond [14]. The SHG efficiency was determined for the undoped and lithium nitrate and nickel sulphate doped $\mathrm{Na}$ $\left(\mathrm{ClO}_{3}, \mathrm{BrO}_{3}\right)$ mixed crystals using a Q-switched high energy
Nd: YAG laser with fundamental wavelength of $1064 \mathrm{~nm}$. The second harmonic generation was confirmed by the emission of green light of wave length $532 \mathrm{~nm}$ from the samples. The SHG efficiency values obtained for the mixed, and $0.5 \mathrm{~mol} \%$ of nickel sulphate doped $\mathrm{Na}\left(\mathrm{ClO}_{3}, \mathrm{BrO}_{3}\right)$ samples are given in table. It is observed from the results that the SHG efficiency is high for $0.5 \mathrm{~mol} \%$ of nickel sulphate doped $\mathrm{Na}\left(\mathrm{ClO}_{3}, \mathrm{BrO}_{3}\right)$ mixed crystal. When compared to the undoped sodium chlorate and sodium bromate mixed crystal.

Table: $6 \mathrm{SHG}$ efficiency for pure and doped $\mathrm{Na}\left(\mathrm{ClO}_{3}, \mathrm{BrO}_{3}\right)$ mixed single crystals

\begin{tabular}{|l|l|l|}
\hline Sample & SHG output mJ & $\begin{array}{l}\text { Efficiency w.r.t. to } \mathrm{Na}_{\left(\mathrm{ClO}_{3}, \mathrm{BrO}_{3}\right)} \\
\text { sample }\end{array}$ \\
\hline $\mathrm{Na}\left(\mathrm{ClO}_{3}, \mathrm{BrO}_{3}\right)$ sample & 11.1 & 1 \\
\hline $\mathrm{NiSO}_{4}$ doped $\mathrm{Na}\left(\mathrm{ClO}_{3}, \mathrm{BrO}_{3}\right)$ sample & 11.9 & 1.0720 \\
\hline
\end{tabular}




\section{CONCLUSIONS}

Mixed sodium chlorate and sodium bromate crystals are NLO materials and they can be used as second harmonic generators of laser light. In the present investigation, the isomorphous crystals such as mixed crystals of sodium chlorate and sodium bromate were grown. The effect of the dopants such as nickel sulphate has been studied in the crystallization of the mixed crystals of sodium chlorate and sodium bromate. In accordance with the solubility data, the saturated solutions of pure, doped and mixed salts were prepared grown by slow evaporation technique. The chemical composition of the the grown doped and mixed crystals was checked by using energy dispersive analysis by X-rays (EDAX) which confirms the presence and replacement of additives in the crystal matrix. Also, powder study for mixed and doped crystals of sodium chlorate and sodium bromate was carried out. The reflection peaks of the XRD patterns were indexed using JCPDS data and unit cell software package. The hardness values of the crystals are varied with the dopants used. The work hardening coefficient values for samples of the work were calculated and found to be altered when the sodium chlorate and sodium bromate crystals are doped with nickel sulphate separately and it is found that the work hardening coefficient is greater than 1.6 for all the samples. The yield stress and stiffness constant values were also determined for the pure and doped crystals.

The FTIR transmission spectra have been recorded in the range of $400-4000 \mathrm{~cm}^{-1}$ for all the grown crystals. The functional groups associated with nickel sulphate separately doped sodium chlorate sodium bromate along with their respective absorption bands and peaks have been identified and assigned. The mixed nickel sulphate doped mixed crystals have good transparency and it was studied by UV-Vis-NIR transmission spectrum. The optical band gap and transmittance values are found to be increased for the doped mixed crystals with respect to the component crystals. The SHG efficiency is varied with respect to the selected dopant materials for mixed crystals.

The surface morphology of the grown crystals was studied by scanning electron microscope (SEM). The micrographs of nickel sulphate doped sodium chlorate and sodium bromate crystals were presented and it is observed that surface of the crystals is smooth and clear with or without crystallites.

\section{ACKNOWLEDGEMENTS}

The authors thank Dr. Peter Koshi, Scientist, XRD (NIIST) National Institute of Interdisciplinary Science and Technology, Trivandrum, Kerala and Dr. P.Prabahara Rao, Scientist, SEM, NIIST, Trivandrum, Kerala for their kind help.The authors gratefully acknowledge Prof.Dr.M.Basheer Ahamed, BSA Univ and Mr.Vincentsagayaraj St.Joseph college, Tiruchy for their timely help.

\section{REFERENCES}

[1] A.S. Lucia Rose., P. Selvarajan., S. Perumal., Growth and Structural, spectral, mechanical, thermal and dielectric Characterization of Phosphoric acid admixture L-alanine (PLA) single crystals., Spectrochimica Acta part A., Vol.81, pp 270 (2011).

[2] N. Vijayan, R.Ramesh Babu, R. Gobalakrishan, S. Dhanuskodi and P. Ramasamy., Journal. Crystal. Growth., 236,407 (2002).

[3] S. Chandrasekahr and M.S. Madhava., Optical Rotary Dispersion of a Mixed Crystal of sodium chloratesodium bromate., Mat. Res. Bull., Vol.4. pp 489 (1969).

[4] P.S.H. Gopalan, M.L. Peterson, G. Crundwell, B. Kahr., Journal Am. Chem. Soc., 115, 3366 (1993).

[5] G. Crundwell, P. Gopalan, A. Bakulin, M.l. Peterson, B. Kahr., Acta Crystallogr. Sect., B53, 189 (1997).

[6] H. Lipson., H.Steeple., "Interperetation of X-ray Powder Diffration Patterns".,

[7] T. Arumanayagam, P. Muruakoothan., Optical Conductivity and Di-electric response of an Organic Aminopyridine NLO single crystals., J. of Materials characterization \&

[8] J. podder, S. Ramalingom, S.N. Kalkura., Cryst. Res. \& Technol., 36, pp 551 (2001).

[9] F. Jesu Rethinam, D. Arivouli and P. Ramasamy., Microhardness studies on doped and strontium tartarate tetrahydrate crystals., J. Mater. Sci Lett., 13, pp 263 (1994).

[10] K. Sangwal, B. Surowska., Mater. Res. Innvat., 7, 91 (2003).

[11] T.Irusan, D.Arivouli and P.Ramasamy., Microhordness Studies on ammomium acid urate crystals., J. Mater.Sci., 12, pp 405 (1993).

[12] S.M.K. Nair and P. Daisamma Jacob., The effect of Doping on the Thermal Decomposition of $\mathrm{NaBrO}_{3}$, Thermochimica Acta., 181, 269 (1991).

[13] D. Arivouli, F.D. Gnanam, P. Ramasamy., J. Mater. Sci. Lett 7., pp 711 (1988).

[14] D. Kalaiselvi, R. Mohan Kumar, and R. Jayavel., ryst. Res. Technol., Vol.8, pp 851 (2008).

[15] D.F.Xue and S.Y.Zhang., Chemical Bond Analysis of Correlation between Crystal Structure and Nonlinear Optical Properties of Complex Crystals., Physica B:Condensed Matter., Vol. 262 pp 78 (1999). 